\title{
Formative assessment: exploring tunisian cooperative teachers practices in physical education
}

\author{
Hasan Melki, Mohamed S. Bouzid, Aymen Haweni, Mourad Fadhloun, Meher Mrayeh, Nizar Souissi \\ Higher Institute of Sport and Physical Education, ISSEP Ksar Saïd, Tunisia
}

\begin{abstract}
Purpose:

This article is based on questions related to the formative assessment of preparatory trainee ship in the professional life of Physical Education teachers. In general, in the first training program, the traineeship represents an integral part of training. In this sense, the traineeship offers a vital opportunity for future teacher to gain practical experience in the real environment, given that formative evaluation is a process of collecting evidence from trainees by cooperative teachers to make decisions about their knowledge and skills, to guide their own instructional activities and to control their behavior. Accordingly, this study proposed to explore practices of Tunisians cooperative teachers in relation to the formative assessment.

Material: $\quad$ To verify our proposed object, we conducted a research using a questionnaire distributed among 96 cooperative teachers in different educational institutions located in the region of the greater Tunis. During the school year 2015-2016, the questionnaire was the subject of a statistical analysis using frequencies and percentages.

Results: $\quad$ The analysis of such data revealed a range of practices about formative estimation among cooperative teachers. In particular, each teacher acknowledged the value of guiding and encouraging student's selfassessment. So that they could lead their students to assume a share of evaluative activity.

Conclusions: Both theoretical and practical implications of these findings are discussed, and some recommendations are made for future practice.

Keywords: Preparatory traineeship, Physical Education, trainee, Cooperative teacher, formative assessment.
\end{abstract}

\section{Introduction}

The first physical education (PE) training in Tunisia has characterized by a dual aspect characteristics: a set of theoretical courses offered by university teacher and practical on the ground experience led by a cooperative teacher (CT) [1]. These collaborative cooperative teachers put their courses available to students so that they could lead teaching activities, guide students in their learning process and manage the class effectively. However, for [2], if a trainee is guided, supervised and trained, he could be able to teach. Through his research, [3] claimed that almost researches on teacher education have showed what kind of teacher intervention affects the success of a course. This cooperative teacher acts as a guide rather more than a model, in which he has to integrate different kinds of theory and practice in any particular lesson. He is also a reflective practitioner and a professional supporter of Skill-developing trainee [4]. Apart from these tasks, cooperative teachers are usually focusing on their pupils and simultaneously on their trainee [5]; therefore, the teacher's role is not uncomplex. Moreover, it has a great influence on the professional development of the trainee [6].

Although the cooperative teachers [4] are the key players in the vocational education, some of them are facing difficulty when they are serving the trainees [7]. Since they are only acting as teachers, they are not likely to feel like an accompanist [8]. In fact, Clerc [9] reported that a good teacher is not necessarily a good mentor. Since the skill of both the cooperative teacher and the ordinary teacher. The cooperative teacher must assume the role

(c) Hasan Melki, Mohamed S. Bouzid, Aymen Haweni, Mourad Fadhloun, Meher Mrayeh, Nizar Souissi, 2017

doi:10.15561/18189172.2017.0505 of evaluator and certify the level of the future teachers' competence even though these trainees feel not at ease before the challenge to match the task that accompanies, and they are under pressure unimaginable when attacking a terminal phase [10]. Assessment performance can be used in different ways by teachers as well as by students [11]. Teachers can use assessment results to identify the students' strengths and weaknesses so that they can tackle them motivate students, and enhance the condition of learning and satisfy their needs from each ability [12]. A formative evaluation is defined as an informal and continuous process embedded in teaching and learning; it is conducted by teachers as a part of their everyday classroom work [13].In fact, there exists a certain gap between the actual and the desired levels of performance while evaluating the comprehension of students, and it is not expressed in marks or grades [12]. In light of this definition, formative assessment is a vital tool for educators to be used integrating accelerative practices and capacity grouping into the traineeship [14]. Assessment embodies a central role in the process of teaching and learning; therefore, its formative function has received regular and remarkable consideration. In fact, some influential works shed light on the vital role of assessment. For example, Clark [15] have demonstrated that formative evaluation is such a powerful way that it can enhance student's learning process in generallyeducated situation. Following Tomlinson [16], formative assessment provides educators facts to support immediate decisions about grouping and stimulation for optimal learning conditions. In addition, the assessment remains a source of concern for many teachers. Delisle and Cantin [17]defines assessment, whether formative or summative, is a very delicate task since teachers are left with their 
own professional judgment without the appropriate tools to confirm their results; it may cause very different and unfamiliar kinds of assessments. Due to the lack of measuring instruments, the cooperative teacher intuitively evaluates trainees' performance creating a risk of bias and injustices [18]. According to Gagné [19], a teacher can use formative assessment to ease decisionmaking through quickening practices. The same author reclaims that many teachers may be unaware of the merits of formative assessment or the ways these practices can be used interactively to adjust instruction effectively. Brookhart [20] said that formative assessment provides teachers information for instructional decisions while it gives pupils information for progress. Many studies have showed that the assessment is a sophisticated task with many challenges for teachers who act as supervisors of the course, and it seems that assessment complexity is partly explained by the different functions it occupies like diagnostic, formative and summative ones [21]. It should also be noted that the assessment responsibility lies not only on the shoulders of the cooperative teacher, but rather on the university supervisor who shares responsibility for evaluating teachers [10]. Gosselin [22] shows that both actors of supervision are not always on the same wavelength. Moreover, the lack of common language is a communicative impediment within the team concerned with supervision [23]. More specifically, formative assessments are used to offer a variety of information for cooperative teachers to make immediate planning decisions about the needs of trainees [24]. To identify needs to inform teachers' practice [25]. To Hughes [26], there are a variety of assessment types, whether formal or informal, among them we can mention stimulating the student's learning through discussions or granting formative feedback of lessons which can be the basis for decision-making in the educational process. Based on their results, Black and Wiliam [25] affirmed that the assessment must be carried out through identifying students' strengths and weaknesses in comprehension as well as in the subject application. As mentioned before, formative assessment is a complex phenomenon influenced by a number of variables [14]. A recent literature have found that to develop successful assessment approaches, it is important to take into consideration teachers' attitudes toward innovations, tools or practice exercises, without mentioning their conceptions of assessment [27]. It is important to take account that an effective formative assessment practice requires a number of conditions to come together such as teachers 'cognition skills and traineeship environment [26]. Formative assessment has been recommended in traineeship as a means of providing information [28], and most researches describe its benefits for underperforming students in areas where extra support or reinforcement is needed [29]. Seen in this light, cooperative teachers often use tools that restrict their evaluative correctness. Similarly, Howe and Ménard [30] asserted that traineeship supervisors would make assessments without the existence of evaluative tools. Furthermore, a cooperative teacher is obliged to assume a dual role with trainees, the role of a guide and that of an assessor [22]. Indeed, they must inform trainees of their strengths and weaknesses. The quality problem is to increase the relationship among actors of supervision and cut the impact of help. In this respect, several cooperative teachers are experiencing discomfort during the period of evaluating trainees [31]. According to these authors, these cooperative teachers are left to their individual professional judgment, because they lack the assessment tools to confirm what they have recorded. They check student's performances and knowledge with guiding feedback acting as a kind of intervention, when assessments show that measuring instruments are absent [17]. As part of the traineeship, the cooperative teachers are generally observing what seems particularly useful for formative assessment [32]. Considering these findings and suggestions, in this article it is better to understand the daily problems and challenges encountered trainees during practices, to support them to resolve their training difficulties and to guide them to develop their pedagogical approaches. Consequently, in this current research, the literature reviews lead us to the following research question: What are the formative assessment strategies used by cooperative teachers as an integral part of the preparatory traineeship to the professional life in EP?

\section{Material and methods}

Design of the Research: The first training in Tunisia was taken over a period of three years ago and entitled to the degree of license in the teaching of physical education. A single preparatory training for a professional life was only held during the third year of training for a period of one continuous school year. The methodological approach is descriptive [33] since it will pave us the way to generate digital data obtained through questionnaires, which in turn will help us give a more accurate picture of the situation [34].

Participants: Participants were 96 cooperative teachers from different educational institutions located in the greater Tunis, who taught a range of grade levels and supervised futures teachers (Table 1). The mean years experience was $9.68(\mathrm{SD}=08.42)$ years (ranging from $0-5$ to 20 years). There was an equal distribution of participants across all categories of this variable, ranging from $19.79 \%$ of the sample at an early stage of their careers to $27.08 \%$. This cross-tabulation between gender and years of experience shows that the majority of respondents were males $(62.5 \%)$ while females were (37.5\%). They are all volunteers accepting to take part in this research study during the school year 2015-2016. We opted for self-administrated questionnaire method in which our participants answered the questionnaire in a way to ensure anonymity. In addition, the average time to complete the task took only 20 minutes.

Procedures: To identify formative assessment practices of cooperative teachers, we inspired to a validated questionnaire of Beauchamp (2013), which used as part of a research on attitudes and behavior evaluation in training at the college level. We have translated and 
adapted the questionnaire to our samples of Tunisians cooperative teachers. Data from closed and open questions were analyzed to identify specific categories related to (a) Identifications of cooperative teacher's roles (b) fixing methods of collecting information (c) knowledge of the impact of different types of assessment practices and (d) moments of formative assessment. For each measure, we developed specific items to address the respective categories. To validate the questionnaire relevant to the new research context, we asked 12 collaborative teachers who both teach and mentor students. They have made constructive comments which enabled us to check, clarify and simplify the questionnaire for the best results when placing the appropriate tools. To avoid response bias in the research, these cooperative teachers have not answered the last questionnaire.

Measures: Participants responded to 33 items on a 5-point Likert-type scale ranging from 1 (very low) to 5 (very high) and they respond to 3 open questions. In fact, we used these second kinds of questions to qualify and clarify the participants' responses as well as to better understand their interpretation of the problem and its impact on the practice. That targeted views that 14 items were retained to identify cooperative teacher's roles, fixing methods of collecting information with 6 items, knowledge of the impact of different types of assessment practices with 5 and 8 items were kept for moments of formative assessment (Table 2). As a result of the quantitative data obtained from the closed questions in the questionnaire, we analyzed such material using the statistical software -SPSS 16 (Statistical Package for social science). Open-end questions as qualitative data were categorized and condensed using word software [27, 35].

\section{Results}

Identifications of cooperative teacher's roles:

A descriptive statistics used to display data and evidence was summarized in the second table, which shows all participants' responses due to the integral roles that the cooperative teachers had played in their formative assessment of future teachers in preparatory traineeship to the professional life. The data demonstrate that there was a broad agreement among participants with the statement that dealt with the fundamental teachers' roles in evaluation. As we can see in table 2, most of the CTs who participated in the survey $(60 \%)$ were in agreement with this statement. Therefore, 58 of 96 cooperative teachers are occupying valuable roles of guidance, encouragement, self-evaluation, motivation and establishing a trusting relationship with students. The consensus among our participants aligns with the results of Acheson and Damien Gall [36] who both insisted upon the necessity of boosting active listening, creating constructive exchange to build a trusting relationship between the student and the teacher , which is the pillar of any relationship. In addition, it is remarkable that 22 Cooperative teachers $(23 \%)$ gave a high priority to the roles of supporting and collaborating with the university supervisor and providing feedback to trainees. In this regard, our results match more the findings of a study conducted by Arpin and Capra [37] whom they claimed that support involves the sharing of experiences between a cooperative teacher and a university supervisor. These authors well praised the interactive relationship and the character of a cooperative teacher. Similarly, Paul [38]

Table 1. Characteristics of the participants included in the study $(n=96)$.

\begin{tabular}{lllll}
\hline Years of experience & Women & Men & Total & Total (\%) \\
\hline $0-5$ years & 10 & 16 & 26 & 27.08 \\
6-10 years & 05 & 14 & 19 & 19.79 \\
$11-15$ years & 10 & 15 & 25 & 26.04 \\
16 - 20 years & 11 & 15 & 26 & 27.08 \\
Over 20 years & 00 & 00 & 00 & 00 \\
Total & 36 & 60 & 96 & \\
Total(\%) & 37.5 & 62.5 & & 100 \\
\hline
\end{tabular}

Table 2. Reliability and Descriptive Statistics for the formative assessment practices of cooperative teachers.

\begin{tabular}{lllll} 
Factor & Sample items & $\begin{array}{l}\text { Nb.of } \\
\text { items }\end{array}$ & $\boldsymbol{\alpha}$ & $\boldsymbol{M}(\boldsymbol{S D})$ \\
\hline $\begin{array}{l}\text { 1.Identifications of cooperative } \\
\text { teacher's roles }\end{array}$ & $\begin{array}{l}\text { Evaluating trainees' learning. } \\
\text { Encouraging self-assessment of trainees. } \\
\text { Guiding students in their developing skills. }\end{array}$ & 14 & 0.72 & $7.15(0.61)$ \\
$\begin{array}{l}\text { 2. Fixing methods of collecting } \\
\text { information. }\end{array}$ & $\begin{array}{l}\text { Self-assessment of the trainee. } \\
\text { Triad discussion. } \\
\text { Dyad discussion. }\end{array}$ & 6 & 0.72 & $7.10(0.52)$ \\
$\begin{array}{l}\text { 3. Knowledge of the impact of } \\
\text { different types of assessment } \\
\text { practices. }\end{array}$ & $\begin{array}{l}\text { Encouraging exchanges with trainees. } \\
\text { Responding to trainees questions. } \\
\text { Questioning trainees. }\end{array}$ & 5 & 0.61 & $6.24(1.22)$ \\
\hline
\end{tabular}


praised a working relationship based on mutual respect between the cooperative teacher and the university supervisor. Therefore, $6 \%$ of teachers attributed an average importance to the relationship between theory and practice and promoted linkages between university training and practical training during traineeship. We note that this low percentage allocated to this role explained by the training absence: they are not abreast of recent changes in physical education, ware of the nature of the student-offered courses during their training. The same percentage of cooperative teachers $(6 \%)$ also attribute low importance to roles based on promoting development of student's self-government and favored the reflexive analysis of trainees. A few teachers, just (4\%), gave a very low importance to the role of mediator between an academic supervisor and interns. As a result of this brief presentation of the various roles and tasks of Tunisians teachers and framers, we are able to notice the complex role of the teacher in framing the process of learning. In fact, planning a lesson is a complicated task whether talking from the position of a teacher or of a trainee supervisor as we are dealing with different learning abilities and various skills in a classroom. The complexity can also be due to the kinds of the adopted strategies by a teacher or due to the teaching practices to which the trainees can refer to learn like practices for internship programs.

In this present study, our significant quantitative findings were supported by qualitative data. So, for the raised question, "Are there other important roles of the cooperative teacher?," we had 10 answers which are as following :Firstly, Two cooperative teachers (20\%) encouraged other teachers to submit a concern form of what the students need. Secondly, four others (40\%) announced that both the psychological and the physical protection of students should be taken into account. Ultimately, a cooperative teacher is someone who mobilizes students in real situations so that they can

Table 3. Degree of importance of cooperative teacher roles.

\begin{tabular}{|c|c|c|c|c|c|}
\hline title & $\begin{array}{l}\text { Very } \\
\text { low } \\
(4 \%)\end{array}$ & $\begin{array}{l}\text { Low } \\
(6 \%)\end{array}$ & $\begin{array}{l}\text { average } \\
(6 \%)\end{array}$ & $\begin{array}{l}\text { High } \\
(23 \%)\end{array}$ & $\begin{array}{l}\text { Very } \\
\text { high } \\
(60 \%)\end{array}$ \\
\hline 1. Collaborating with the university supervisor. & & & & $\mathrm{x}$ & \\
\hline 2. Supporting the university supervisor & & & & $x$ & \\
\hline $\begin{array}{l}\text { 3. Mediating between the university supervisor and } \\
\text { trainees. }\end{array}$ & $\mathrm{x}$ & & & & \\
\hline 4. Guiding students in their developing skills. & & & & & $x$ \\
\hline 5. Gathering information on the progress trainees. & & & & & $\mathrm{x}$ \\
\hline 6. Promoting the development of trainees' autonomy. & & $x$ & & & \\
\hline 7. Establishing a relation between theory and practice. & & & $x$ & & \\
\hline 8. Accompanying reflective analysis of trainees. & & $x$ & & & \\
\hline 9. Providing feedback to trainees. & & & & $x$ & \\
\hline 10. Maintaining a relationship of trust with trainees. & & & & & $x$ \\
\hline 11. Encouraging professionalism. & & & $x$ & & \\
\hline 12. Encouraging self-assessment of trainees. & & & & & $x$ \\
\hline 13. Mobilizing trainees' difficulties. & & & & $x$ & \\
\hline 14. Evaluating trainees' learning. & & & & & $\mathrm{x}$ \\
\hline
\end{tabular}

face challenges and difficulties and is the one who takes responsibility to solve the students' problems during lessons of physical education.

Identification of information collection methods for CT:

Regarding the question, "do you think of preserving the effectiveness and the efficiency of these methods of gathering information?, " it is raised to show the various methods used to collect data from the student's progress toward the fulfilled goals of any particular lesson or toward any faced learning difficulties. Our findings suggest that chosen teaching method with 26 replies (27\%), followed by a method of trainees' direct observation (26\%). This shows that there is a statistically significant difference in the efficiency of information collection methods for cooperative teachers. It proves that the highest level of cooperative teachers $(21 \%)$ engaged dyadic discussion (teacher and teacher trainee), 15 people (16\%) used the discussion in dyad (CT and US) and that 10 cooperative teachers used the triad discussion. We found that CTs lead students to assume a share of assessment activity. They actively involve students in the process of evaluation and lead them to make their reflexive assessment.

Effectiveness of information gathering tools:

"What tools used to gather information about students' progress and difficulties?"

Our results show that descriptive matrix, (CT 64, or $67 \%$ ) and class newspaper $(20 \%)$ occupied the first rank as the most used teaching tools, whereas self-assessment was found the least as a teaching and learning task ( just 8 participants opted it for ). The final rank was for checklist (5\%). Among the responses about the effectiveness of an information gathering tool to assess students' progress and difficulties, only 20 cooperative teachers have used professional evaluative judgments while the rest have avoided answering the question. during a lesson self-assessment was the most commonly 
Impact of various types of the cooperative teacher practices:

On the basis of the findings set out in Table 3, we can conclude the following: firstly, various kinds of cooperative teacher's practices were adopted to determine the impact evaluation of skills development on the trainees. In fact, most of the cooperative teachers' assessment responses to these practices had a medium, high or very high impact. Secondly, only three practices were identified as having the largest influence, and only 9 CT (9.37\%), whom they acted as experts with the students, gave their opinions on the interventions of the trainees. Finally, the last practice influence was very low to reinforce trainees to develop their personal and professional competence.

To support our results, we asked a cooperative teacher an open question; "What is the key moment of the formative evaluation internship for you?"

On the basis of the results set out in Graph1, we can deduce that most cooperative teachers opted for the midstage as the perfect period of formative assessment. It was also noted that 16 participants $(16.66 \%)$ chose the observation reinvestment in learning during training activities, while others $(9.37 \%)$ preferred direct observation in the field with immediate feedback during a lesson. In short, formative assessment can be an effective teaching process to check students' understanding if it is performed during and before traineeship. In light of our results, we can say that most teachers believe that cooperative strategies, halfway through the course, are now essential to the formative assessment of the traineeship.

\section{Discussion}

Our task was to know formative assessment methods, not only to show the most comfortable emotional conditions for successful implementation of cooperative teachers' supervision activities, but also to bring these conditions to the real monitoring situation process. In this proposed article, we chose to focus on the practices of Tunisians teachers' and coaches in relation to the formative assessment methods used as preparatory traineeship to the professional life. It is these essential actors in the field that grant real training courses to students without the official status of cooperative teachers and take paramount roles in the curriculum construction of instruction [39]. We believe that they have the sufficient resources they need to well perform their roles, to adopt their interventions in the context of the internship, to analyze and justify their practices as competent social actors [40] reflecting

Table 4. Impact of CT practices on developing trainees' skills

\begin{tabular}{|c|c|c|c|c|c|c|}
\hline title & & $\begin{array}{l}\text { Very } \\
\text { low } \\
(\%)\end{array}$ & $\begin{array}{l}\text { Low } \\
(\%)\end{array}$ & $\begin{array}{l}\text { Average } \\
(\%)\end{array}$ & $\begin{array}{l}\text { High } \\
(\%)\end{array}$ & $\begin{array}{l}\text { Very } \\
\text { High } \\
(\%)\end{array}$ \\
\hline 6.1 & $\begin{array}{l}\text { Promoting the equal exchange of ideas with } \\
\text { trainees }\end{array}$ & 4.16 & 9.37 & 30.2 & 35.41 & 20.83 \\
\hline 6.2 & Replying on traines' questions & 00 & 00 & 9.37 & 52.05 & 38.54 \\
\hline 6.3 & $\begin{array}{l}\text { Giving their opinion in trainees' } \\
\text { interventions }\end{array}$ & 00 & 4.16 & 28.12 & 52.05 & 15.67 \\
\hline 6.4 & Providing tools for reflection & 00 & 00 & 15.67 & 30.33 & 54.00 \\
\hline 6.5 & Assessing student's performance & 00 & 00 & 20.63 & 41.17 & 38.2 \\
\hline 6.6 & Questioning trainees & 00 & 10.8 & 00 & 37.33 & 51.87 \\
\hline 6.7 & Acting as expert with trainees & 00 & 4.16 & 43.8 & 34.28 & 17.76 \\
\hline 6.8 & $\begin{array}{l}\text { Asking trainees to justify their choice of } \\
\text { intervention }\end{array}$ & 00 & 00 & 15.67 & 52 & 32.33 \\
\hline
\end{tabular}

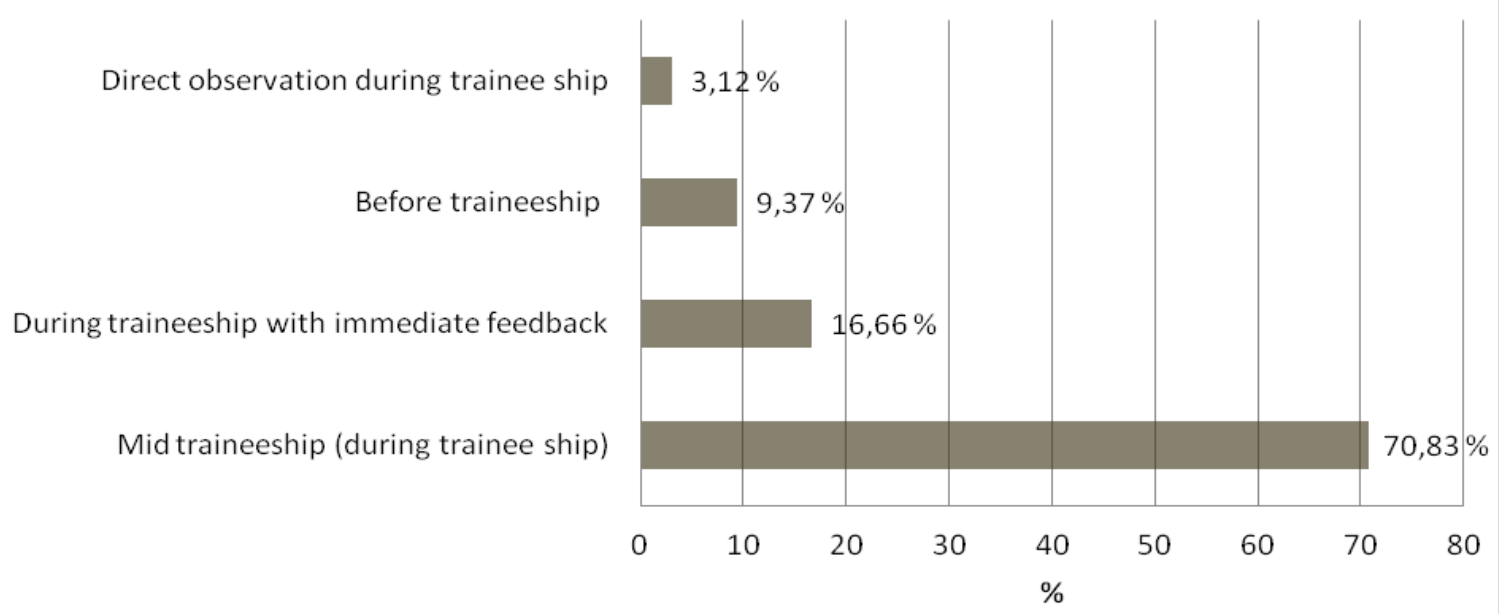

Figure 1. Moment of formative assessment training. 
on their practice to help participants [41] and to control the reflective practitioner [42]. In addition, they pave the way for students to assume a share of evaluative activity. Similarly, Misset et al [14] indicated that cooperative teachers need to perform self-assessment to their trainees so that they could become autonomous and reflective thinking power. Like many researches who have claimed that formative assessment in training is complex and challengeable task for cooperative teachers acting as supervisors of traineeship [21], these roles are based on promoting development of student's self-government and come along with the reflexive analysis of trainees. In their research, Charpenter and Duchene [43] came to the conclusion that a cooperative teacher must work to allow trainees to become autonomous by developing their own professional skills. Besides, it has been believed that mistakes can develop the personality of a trainee and provide opportunities for better self-improvement and learning. However, Altet, Paquay et al[44] argued that a cooperative teacher should take into consideration that a trainee is not a perfect being, but can turn mistakes into opportunities for a better rebound. Brookhart [20] commented that CTs must help their students to find solutions despite the complex and challengeable tasks. Consequently, they will be capable to develop their resourcefulness through the flexibility to adapt to any kind of faced problem. In this sense, Robillard and St. Louis [45] emphasized on the importance of the training relationship between a practitioner and a trainer. Moreover, Black et al. [25] have clearly identified peer assessment as one of the key features of formative assessment. We also learned that the main methods used to collect information about the progress and difficulties of trainees toward learning goals are self-assessment, followed by a method of direct observation during the placement support. We found that cooperative teachers encourage students to assume a share of evaluative activity. They actively involve students in the process of assessment and leading them to reflective thoughts. Andrade \& Cizek, [24] highlighted the same point indicating that the field of traineeship needs self-evaluation so that we could develop autonomy and reflexivity in the character of trainees. For Gaudreau [46], observation is an efficient process or tool to collect information about trainees. In his study, he put a great emphasis on the trainee's observation to prevent any rupture and interference. Similarly, Tomlinson [16] claimed that if observation is performed to gather information, it must be done under specific conditions by using instruments developed for the use of real life situations. Furthermore, we have learned that the narrative assessment grid and the school are the most used tools by cooperative teachers to gather information about students. The less used were the self-assessment and checklist. Our analysis leads us to the Scallon's [47] affirmation which mentioned that the descriptive assessment grid is one of the most formative assessment tools. It should also be noted that class newspaper is among the suggested tools by Leroux [48] that occupies an integral part in the formative assessment. Regarding the discussion between the trainee and the cooperative teacher, Vanhulle [49] sheds light on the paramount role of teachers in helping students develop a balanced personality through the recognition of different styles of learning and contributing teacher trainer in the teaching practices and vice versa. The interactions between the student and the cooperative teacher must take place with respect to an appropriate learning environment. Similarly, Black \& Wiliam [13] spoke of joint construction activities that take place in clear and harmony environment and involve alternating initiatives. Hence, our analysis leads us to the affirmation of Pelpel [8], which defined the formative observation of the trainee as a care process that goes beyond the look and left before the assessment or intervention. He also claimed that an instrumented observation provides direct access to the practice of the intern and analysis of educational activities to improve certain aspects. We must also remember that the grid of a descriptive assessment is one of the most appropriate formative evaluative tools, according to Scallon [47]. It is worth noting that the class journal is also among the tools offered by Leroux [48] as an integral part of formal assessment. Based on the results of the raised question about the effectiveness of an information gathering-tool, only 20 cooperative teachers have used professional evaluative judgments while the rest have avoided answering this question.

In addition we have found that our result is compatible with that Lafortune [50] definition that he has defined professional judgment as a process that leads to a professional ability. Availability, communication skills, respect, understanding and the ability to listen are the major qualities of cooperative teachers who perceived as having the high impact of teaching practices while involving with trainees during traineeship. These qualities are essential to establish a climate of confidence and to help to make sure that students feel comfortable with the placement supervisor [50]. Otherwise, we know that a defensive attitude for students contributes to a non-receptivity to comments, which much affects their learning [26].

\section{Conclusion}

Our research results allow us to draw a valid conclusion about the importance of formal assessment in internship and the role of the teacher as a facilitator of the learning process. In fact, formative assessment strategies considered to be more effective instructional strategies because they carry discussion in dyad and triad, the feedback from construction as well as strategy-promoting question and reflection. In terms of the impact of different CT practices on the development of the trainees' skills, we have found that most of the supporting practices are those perceived as the most effective for instructing teachers [12]. The data have also showed that the practices that generate trainees' interrogation and reflection are generally qualified as having a significant impact. They are also among the best supporting and encouraging teaching strategies since accompanying strategies instilling reflection were proposed by Van Nieuwenhoven 
and Labeeu [51] and supporting analysis in practice were presented by Guillemette and Lapointe [52]. For their part, the practices which put EA as an expert have more varied opinions. We see the same phenomenon for the practice of trade on equal terms with the trainees. This leads us to think that authority question within the trainer and trainee is complex. All participants in our research consider that $\mathrm{CT}$ qualities proposed in the questionnaire have a major impact on the effectiveness of interventions.

The relationship of trust between the cooperative teacher and students occupy a fundamental place. Ultimately, the midterm review is the perfect time of performing formative assessment in traineeship. Therefore, it would be interesting to focus on the point of view of students and the development of their skills during the trainship, which could be a prospect to deepen.

\section{Acknowledgments}

The authors are grateful to the participating cooperative teachers.

\section{Funding}

The author(s) received no financial support for the research, authorship, and/or publication of this article.

\section{Conflict of interests}

The authors declare that there is no conflict of interests.

\section{References}

1. Melki H, Bouzid MS, Hawani A, Mrayeh M, Souissi N. Identification of Prevailing Roles to Which Tunisian Cooperative Teachers (CT) Attach a Big Importance in Accompanying Teacher Students (TS). Creative Education, 2016;7(09):1244. doi:10.4236/ce.2016.79131

2. Acheson KA, Gall MD. La supervision pédagogique. Méthodes et secrets d'un superviseur clinicien. Logiques. [Pedagogical supervision. Methods and secrets of a clinical supervisor. Logical]. 1993. (in French)

3. Boudreau P. Que se passe-t-il dans un stage réussi? [What is happening in a successful internship?] Revue des sciences de l'éducation, 2001; 27(1):65-84. (in French)

4. Portelance L. Analyse des perceptions du soutien d'un enseignant associé à la formation du stagiaire [Analysis of perceptions of teacher support associated with trainee training]. Éducation et francophonie, 2010; 38(2): 21-38. (in French)

5. Perrenoud P. Les cycles d'apprentissage: une autre organisation du travail pour combattre l'échec scolaire [Learning Cycles: Another Work Organization to Combat Educational Failure]. PUQ; 2002. (in French)

6. Talvitie U, Peltokallio L, Mannisto P. Student teachers' views about their relationships with university supervisors, cooperating teachers and peer student teachers. Scandinavian Journal of Educational Research, 2000;44(1): 79-88. doi:10.1080/713696662

7. Durand M. L'enfant et le sport. [Children and sport]. Presses universitaires de France; 2000. (in French.

8. Pelpel P. Accueillir, accompagner, former des enseignants. [Greet, accompany, train teachers]. Chronique sociale; 2003. (in French)

9. Clerc F. Former des praticiens-formateurs. La formation des enseignants sur le terrain. [Train practitioners-trainers. Teacher training in the field]. Paris: Hachette Éducation; 1998. (in French)

10.Provencher Y. Aide sociale au Nouveau-Brunswick: Le discours des personnes assistées sociales aux sujets de leurs rapports avec leur gestionnaire de cas [Social Assistance in New Brunswick: Welfare Recipients' Discourse on Relationship to Case Manager]. Canadian Review of Social Policy/Revue canadienne de politique sociale. 2000;59:1421. (in French)

11. Morrison FJ, Connor CM, Bachman HJ. The transition to school. In: D. K. Dickinson, \& S. B. Neuman (Ed.), Handbook of early literacy. New York, NY: Guilford Press; 2005;2:111-135. doi:10.1080/19345747.2010.510179

12.Kitiashvili A. Teachers' attitudes toward assessment of student learning and teacher assessment practices in general educational institutions: The case of Georgia. Improving Schools, 2014;17(2):163-175. doi:10.1177/1365480214534543

13.Black Paul, Harrison Chris, Lee Clara. Assessment for learning: Putting it into practice. McGraw-Hill Education (UK); 2003

14. Missett TC, Brunner MM, Callahan CM, Moon TR, Price Azano A. Exploring teacher beliefs and use of acceleration, ability grouping, and formative assessment. Journal for the Education of the Gifted, 2014; 37(3): 245-268. doi: $10.1177 / 0162353214541326$

15.Clark I. Formative assessment: 'There is nothing as practical as a good theory'. Australian Journal of Education, 2010; 54(3), 341-352. doi:10.1177/000494411005400308

16.Tomlinson CA. The differentiated classroom: Responding to the needs of all learners. Alexandria, VA: Association for Supervision and Curriculum Development; 1999.

17.Delisle S, Cantin G. Évaluation en stage un modèle de grilles. [Internship evaluation a grid pattern]. 1994. (in French)

18.Robidas G, Fredette JC. Grilles d'évaluation formative et sommative des habiletés d'exécution dans différents profils de l'enseignement professionnel [Formative and summative assessment grids of performance skills in different vocational education profiles].1984. (in French)

19.Gagné F. Academic talent development and the equity issue in gifted education. Talent Development \& Excellence, 2011; 3: 3-22.

20.Brookhart SM. Expanding views about formative assessment: A review of the literature. In: H. McMillan (Ed.), Formative assessment classroom: Theory into practice. New York, NY: Teachers College Press; 2007.

21.Borges C, Séguin C. Le soutien aux stagiaires en difficulté en formation initiale en éducation physique et à la santé. Quand le stage en enseignement déraille: regards pluriels sur une réalité trop souvent occultée. [Supporting students in difficulty in initial training in physical education and health. When teaching internship derails: plural views on a reality too often obscured]. 2013. (in French)

22.Gosselin L. Les modalités en français: la validation des représentations [ The modalities in French: the validation of representations]. 2010. (in French)

23.Boutin G. Les recherches sur la triade et leur contribution à la formation des enseignantes et des enseignants. La recherche en formation des maîtres: Détour ou passage obligé sur la voie de la professionnalisation. [Research on the triad and their contribution to the training of teachers. Research in teacher training: Detour or necessary step 
towards professionalization]. 1993. (in French)

24. Andrade HL, Cizek GJ. Handbook of formative assessment. New York, NY: Routledge; 2010.

25.Black P, Wiliam D. Assessment and classroom learning. Assessment in Education: Principles, Policy, \& Practice, 1998; 574:56-65. doi:10.1080/0969595980050102

26.Hughes GB. Formative assessment practices that maximize learning for students at risk. In: H. Andrade \& G. Cizek (Ed.), Handbook of formative assessment. New York, NY: Routledge; 2010.

27.Azano A. The Posssibility of Place: One Teacher's Use of Place-Based Instruction for English Students in a Rural High School. Journal of Research in Rural Education (Online), 2011;26(10):1-10.

28.Smith SR, Wiggins CM, Gorske TT. A survey of psychological assessment feedback practices. Assessment, 2007; 14(3), 310-319. doi:10.1177/1073191107302842

29.Shute V. Focus on formative feedback. Review of Educational Research, 2008;78:153-189. doi:10.3102/0034654307313795

30. Howe R, Ménard L. Croyances et pratiques en évaluation des apprentissages. [Beliefs and practices in evaluation of learning]. Laval: Cégep Montmorency (PAREA); 1993. (in French)

31.Desbiens JF, Borges C, Spallanzani C. Investir dans la formation des personnes enseignantes associées pour faire du stage en enseignement un instrument de développement professionnel [Investing in the Training of Associate Teachers to Make Teaching Internship an Instrument of Professional Development]. Éducation et francophonie, 2009;37(1): 6-25. (in French).

32.Molina EC, Gervais C. Les stages en formation à l'enseignement: pratiques et perspectives théoriques [Teacher training courses: theoretical practices and perspectives]. PUQ; 2008. (in French)

33.Fortin M.-F. Fondements et étapes du processus de recherche. Méthodes quantitatives et qualitatives [Foundations and stages of the research process. Quantitative and qualitative methods]. Montréal: Chenelière éducation; 2010. (in French)

34.Karsenti T, Savoie-Zajc L. La recherche en éducation. Étapes et approches [Research in education. Steps and Approaches]. 2011. (in French)

35.Maxwell JA. Conceptual framework: What do you think is going on. Qualitative research design: An interactive approach, 2005;41:33-63.

36. Acheson K Gall, Et Gall M. Techniques in the Clinical Supervision of teachers. 2005.

37.Arpin L, Capra L. Accompagner l'enseignant dans son parcours professionnel [Accompany the teacher in his / her professional career]. Montréal: Chenelière Éducation; 2008. (in French).

38.Paul Rhea. Language disorders from infancy through adolescence: Assessment \& intervention. Elsevier Health Sciences; 2007.

39. Van Nieuwenhoven C, Colognesi S, Bothy É, Wattiez R. Une recherche collaborative sur l'accompagnement des futurs instituteurs: un levier de développement professionnel pour les maîtres de stage [A collaborative research on the support of future teachers: a lever of professional development for the tutors]. Evaluer. Journal International de Recherche en Education et Formation, 2015;1(2):103-12.. (in French)

40.Stevenson JL, Lindley CE, Murlo N. Retrospectively Assessed Early Motor and Current Pragmatic Language Skills in Autistic and Neurotypical Children. Perceptual and Motor Skills. 2017; 124(4):777-794. doi:10.1177/0031512517710379

41.Desgagné S. Le concept de recherche collaborative: l'idée d'un rapprochement entre chercheurs universitaires et praticiens enseignants [The concept of collaborative research: the idea of a rapprochement between university researchers and teaching practitioners]. Revue des sciences de l'éducation, 1997;23(2):371-393. (in French)

42. Schon Donald A. The reflective practicioner: how professionals think in action. New York: Basic Books; 1983.

43.Charpentier C, Duchène M. L'accompagnement, un certain rapport des hommes entre eux.[ Accompaniment, a certain relationship between men]. Sciences-Croisées, 2009;5:2532. (in French)

44.Altet M, Paquay L, Perrenoud P. Formateurs d'enseignants: quelle professionnalisation? [Teacher educators: what professional?]. De Boeck Supérieur; 2002. (in French)

45.Robillard D, Saint-Louis F. Le partenariat, un lieu privilégié de formation continue pour l'enseignant de métier. $D$. Raymond \& Y. Lenoir. Enseignants de métier et formation initiale: des changements dans les rapports de formation à l'enseignement. [Partnership, a privileged place of continuing education for the trade teacher. D. Raymond \& Y. Lenoir. Trades Teachers and Initial Training: Changes in Teacher Education Reports]. Bruxelles-Paris: De Boeck; 1998. (in French)

46.Gaudreau L. Évaluer pour évoluer. Les indicateurs et les critères [Evaluate to evolve. Indicators and criteria]. Outremont: Les éditions Logiques; 2001. (in French)

47.Scallon G. L'évaluation formative des apprentissages [Formative assessment of learning]. Presses Université Laval; 1988. (in French)

48.Leroux JL. Évaluer pour faire apprendre. Se former à la pédagogie de l'enseignement supérieur [Evaluate for learning. Training in Higher Education Pedagogy]. 2014. (in French)

49.Vanhulle S. Dire les savoirs professionnels: savoirs de référence et logiques d'action [Saying professional knowledge: reference knowledge and action logics]. De Boeck Supérieur; 2009. (in French)

50.Lafortune L. Accompagnement-recherche-formation d'un changement en éducation: un processus exigeant une démarche de pratique réflexive [Accompaniment-researchtraining for change in education: a process requiring a reflective practice]. Revue des HEP de Suisse romande et du Tessin: Formation et pratiques d'enseignement en questions, 2006;5:187-202.. (in French)

51.Van Nieuwenhoven C, Labeeu M. L'accompagnement par le superviseur lors de l'entretien à chaud dans un curriculum à visée réflexive [Supervisor support during hot interview in a reflective curriculum]. Éducation et francophonie, 2010;38(2):39-59. (in French)

52.Guillemette F, Lapointe JR. L'autoformation du stagiaire. Favoriser la progression des stagiaires en enseignement [The trainee's self-training. Promote the progression of teaching trainees]. 2011. (in French) 
Information about the authors:

Hasan Melki; http://orcid.org/0000-0001-5387-4279; hmelki@yahoo.fr; Higher Institute of Sport and Physical Education; Ksar Saïd 2010, MANOUBA, Tunisia.

Mohamed. S. Bouzid; http://orcid.org/0000-0002-0876-5177; med.sami.bouzid@gmail.com; Higher Institute of Sport and Physical Education; Ksar Saïd 2010, MANOUBA Tunisia.

Aymen Haweni; http:// orcid.org/0000-0001-9214-8050; hawani-aymen@yahoo.com; Higher Institute of Sport and Physical Education; Ksar Saïd 2010, MANOUBA Tunisia.

Mourad Fadhloun; http://orcid.org/0000-0003-3803-2086; ScopusAuthorID: 35740151200; mfadhloun@yahoo.fr; Higher Institute of Sport and Physical Education; Ksar Saïd 2010, MANOUBA Tunisia.

Meher Mrayeh; http:// orcid.org/0000-0002-4544-8138; mrayeh-meher@gmail.com; Higher Institute of Sport and Physical Education; Ksar Saïd 2010, MANOUBA Tunisia.

Nizar Souissi; http:// orcid.org/0000-0003-1129-6727; n.souissi@yahoo.fr ; Higher Institute of Sport and Physical Education; Ksar Saïd 2010, MANOUBA Tunisia.

Cite this article as: Hasan Melki, Mohamed S Bouzid, Aymen Haweni, Mourad Fadhloun, Meher Mrayeh, Nizar Souissi. Formative assessment: exploring tunisian cooperative teachers practices in physical education. Pedagogics, psychology, medicalbiological problems of physical training and sports, 2017;21(5):227-235. doi:10.15561/18189172.2017.0505

The electronic version of this article is the complete one and can be found online at: http://www.sportpedagogy.org.ua/index.php/PPS/issue/archive

This is an Open Access article distributed under the terms of the Creative Commons Attribution License, which permits unrestricted use, distribution, and reproduction in any medium, provided the original work is properly cited (http://creativecommons.org/licenses/by/4.0/deed.en).

Received: 25.08.2017

Accepted: 19.09.2017; Published: 25.09.2017 